\title{
Design and Evaluation of a Corn Silage Harvester Using ShredDing AND Flail CutTing
}

\author{
M. Zhang, M. L. Sword, D. R. Buckmaster, G. R. Cauffman
}

\begin{abstract}
A corn silage harvester using a shredding/crushing mechanism was designed, fabricated, and tested during two harvesting seasons with the objective of improving the feed value of corn silage. Two pairs of toothed rolls turning at different speeds shredded whole-plant corn. Corn stalks were shredded, kernels were broken, and cobs were crushed. Average specific energy required to shred whole-plant corn ranged from 2.5 to $5.9 \mathrm{kWh} / \mathrm{Mg}$ DM. Average specific energy for an added flail cutter/blower ranged from 2.0 to $4.7 \mathrm{kWh} / \mathrm{Mg}$ DM for a total harvester specific energy requirement of 4.5 to $10.6 \mathrm{kWh} / \mathrm{Mg}$ $D M$. Average specific energy requirements for shredding varied significantly among different roll speed treatments at a unit roll force of $15 \mathrm{~N} / \mathrm{mm}$ (front and rear), but no significant effect of roll speed configuration was found at other unit roll forces. Packed density was lower for shredded silage than for chopped silage, but shredded and chopped samples both ensiled well with $\mathrm{pH}$ values of 3.8 to 4.1 after fermentation. Particle size distributions of shredded and flail-cut samples were similar at moisture levels of 60\% and 65\% w.b.; however, the 70\% moisture crop was coarser. Shredding produced fewer small particles $(<9 \mathrm{~mm})$ and more large particles $(>9 \mathrm{~mm})$ than chopping, while shredded and flail-cut samples had more small particles and more large particles than chopped samples.
\end{abstract}

Keywords. Corn silage, Effective fiber, Forage harvester, Kernel processing, Particle size, Shredding, Specific energy.

$\mathrm{E}$ conomic pressures on dairy and beef cattle producers have increased interest in quality of wholeplant corn silage (Johnson et al., 1999). One attempt to improve forage quality has been the use of roll processing. When corn silage is harvested at more mature stages, uncracked grains are more difficult to digest. Honig and Rohr (1982) reported that as much as $25 \%$ of mature, uncracked kernels in corn silage may be undigested and end up in feces. With mechanical processing, a pair of toothed rolls having narrow clearance is placed behind the harvester cutterhead to break the corn kernels and thus improve digestion of starch within the grain. Increased theoretical length of cut (TLC) (12 to $20 \mathrm{~mm}$ ) combined with processing of whole-plant corn silage has improved animal performance compared to control diets comprised of short TLC unprocessed corn silage (Bal et al., 2000; Johnson et al., 1999; Shinners et al., 2000).

Since kernel processing reduces the particle size of stover, a longer chop length has been recommended to obtain longer yet very digestible forage material (Hoover et al., 1998; Johnson et al., 2002; Roberge et al., 1998; Savoie, 1997;

Article was submitted for review in December 2002; approved for publication by the Power \& Machinery Division of ASAE in September 2003.

The authors are Min Zhang, Former Research Assistant, Michael L. Sword, ASAE Member Engineer, Former Research Assistant and Engineer, Kuhn Knight, Inc., New London, Ohio, Dennis R. Buckmaster, ASAE Member Engineer, Associate Professor, Department of Agricultural and Biological Engineering, and Glenn R. Cauffman, Farm Operations Manager, Pennsylvania State University, University Park, Pennsylvania. Corresponding author: Dennis R. Buckmaster, 230 Agr Engineering Building, Pennsylvania State University, University Park, PA 16802; phone: 814-865-3392; fax: 814-863-1031; e-mail: drb3@psu. edu.
Shinners et al., 2000). Adequate forage roughage and proper physical and chemical traits are necessary for proper ruminal function in dairy cows. When minimum effective fiber levels are not met, cows often exhibit metabolic disorders including reduced total DM digestibility, reduced milk fat, displaced abomasums, and an increase in the incidence of laminitis, acidosis, and fat cow syndrome (Nocek, 1997; Armentano and Pereira, 1997; Owens et al., 1998). Effective fiber is an interaction between chemical fiber measured as neutral detergent fiber (NDF) and particle size.

Shredding of herbage crops to split stems and increase surface area has been shown to be beneficial as it enhances fermentation, improves intake, and facilitates ruminal degradation of forage fiber (Koegel et al., 1992; Petit et al., 1994; Charmley et al., 1997). In a simulation study, Rotz et al. (1999) predicted that kernel processing of corn silage could increase farm profitability by providing about a $2 \%$ increase in milk production and a $\$ 50 / \mathrm{cow}$ increase in annual net return.

If it were possible to increase forage surface area, yet maintain physical length for effective fiber, perhaps a much better feed could be generated. In their review of the nutritive value of processed corn silage, Johnson et al. (1999) concluded that mechanical forage processing provided forage that ensiled more quickly and had less DM loss during ensiling; digestibility of starch and fiber and milk production were increased.

Besides the nutritive benefits, processing may require less energy than chopping and produce a feed that is easier to pack. Shinners et al. (1987a) concluded that longitudinal shear energy was about $10 \%$ of transverse shear energy per unit area in alfalfa maceration. Maceration facilitated compaction in that macerated material was more compliant (Hintz et al., 1999; Shinners et al., 1987b). The released juice and starch of kernels may also make more sugar and starch 
available for fermentation. With the objective of making corn silage without chopping, an experimental prototype harvester was developed. The specific objectives addressed in this article are:

- To design and fabricate a forage harvester that shreds with narrow clearance rolls and subsequently cuts and blows with a flail.

- To evaluate the effect of processing roll configuration on energy consumption, particle size, and compaction of the processed whole-plant corn.

- To evaluate the effect of flail configurations on energy consumption and the particle size of the processed wholeplant corn.

\section{DESign OF THE HARVESTER}

\section{Shredding Mechanism}

A two-row forage harvester (New Holland model 718) provided the base unit with four feeding rolls and a cutting cylinder. The cutting cylinder was removed and replaced by two pairs of $152 \mathrm{~mm}$ diameter processing rolls. Crop material was crushed and shredded between the nip points of the two sets of rolls. The flail cutting/blowing mechanism was added after the shredding roll system was field tested. Both the shredding rolls and the flail cutting/blowing mechanism were driven hydraulically to allow easy speed adjustment.

The two pairs of rolls were arranged to convey shredded material upward (figs. 1 and 2). The rolls were loaded by compression springs, and the minimum spacing between the rolls and the roll unit forces were adjustable. Within each pair of rolls, whole corn plants were subjected to shear forces caused by the differential speed of teeth on the roll surfaces and compressive forces caused at the nip points of the roll pairs. Between the two sets of rolls, plants were subjected to tensile stress.

The outer surfaces of the four processing rolls were grooved parallel to the axis of rotation; the $\mathrm{V}$-shaped grooves were spaced $6.1 \mathrm{~mm}$ apart with a $60^{\circ}$ angle and a depth of $5.7 \mathrm{~mm}$. Two compression springs (spring constant of $272 \mathrm{~N} / \mathrm{mm}$ ) at each shaft end allowed vertical displacement of both rolls that adjusted to the variable thickness of material passing between the rolls. Hydraulic motors powered the rolls. Minimum clearance within a roll pair was adjustable from 1 to $15 \mathrm{~mm}$. The centerline of the front pair of rolls was at a $15^{\circ}$ angle to the horizontal line, and the rear pair was at a $15^{\circ}$ angle to the front pair, so shredded forage was discharged at an angle of $30^{\circ}$ from horizontal. The distance between the nip points of the rolls was fixed at $330 \mathrm{~mm}$, the shortest distance allowed by the physical constraints of the roll and bearing support brackets.

A pair of PTO-driven hydraulic tandem gear pumps generated flow to power four hydraulic motors connected to each of the four rolls (Cauffman, 2002). Each pump powered two hydraulic motors in series, which corresponded to one pair of rolls. The four fixed displacement hydraulic gear motors were identical. The flow rate to the motors was adjusted using flow control valves to obtain different roll speeds; the bottom rolls of each pair always had the higher speed. Directional control valves were used to reverse the rolls in case of plugging. Counterbalance valves were used to set pressure loading to the two motors that drove each of the two slower rolls; these ensured a speed differential within pairs to avoid overrunning of the slower rolls (Zhang, 2002).

\section{Flail Cutting Mechanism}

The cutter/blower was added after initial tests to reduce length of long forage segments and help propel harvested material. The mechanism had four pins each with up to six flails (fig. 1; Sword, 2002). The flail system was driven directly by a hydraulic motor, which was powered by the tractor hydraulic system. The rotational speed was controlled by adjusting the flow control valve of the tractor hydraulic system.

Tip speed of the cutter/blower was crucial for conveying forage to a trailing wagon. Chattopadhyay and Pandey (2001) determined that $40 \mathrm{~m} / \mathrm{s}$ was an optimal flail tip velocity to provide adequate blowing of maize; therefore, the $0.41 \mathrm{~m}$ diameter flail mechanism was required to rotate at least $1800 \mathrm{rpm}$. Upward cutting, similar to that utilized by Shinners et al. (1991), was used in an attempt to reduce specific energy requirements of the forage harvester.

\section{Testing AND Evaluation \\ Testing OVerview}

Field experiments were carried out using whole-plant corn. Field experiments were done during two harvest seasons: fall 2000 and fall 2001. Three sets of experiments were completed on medium to low moisture corn forage (67\% to $51 \%$ w.b.) in fall 2000 ; corn with moisture levels from $70 \%$ to $60 \%$ w.b. was tested in fall 2001 . Factors studied included: roll speed differential, minimum roll clearance,

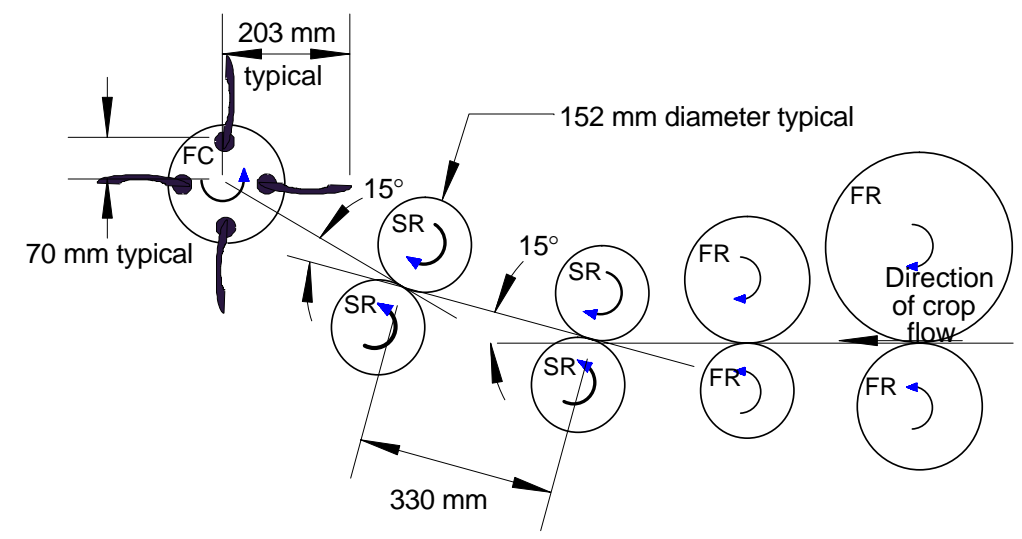

Figure 1. Side-view schematic of the shredding harvester $(\mathrm{FR}=$ feed rolls, $\mathrm{SR}=$ shredding rolls, and $\mathrm{FC}=$ flail cutter/blower $)$. 


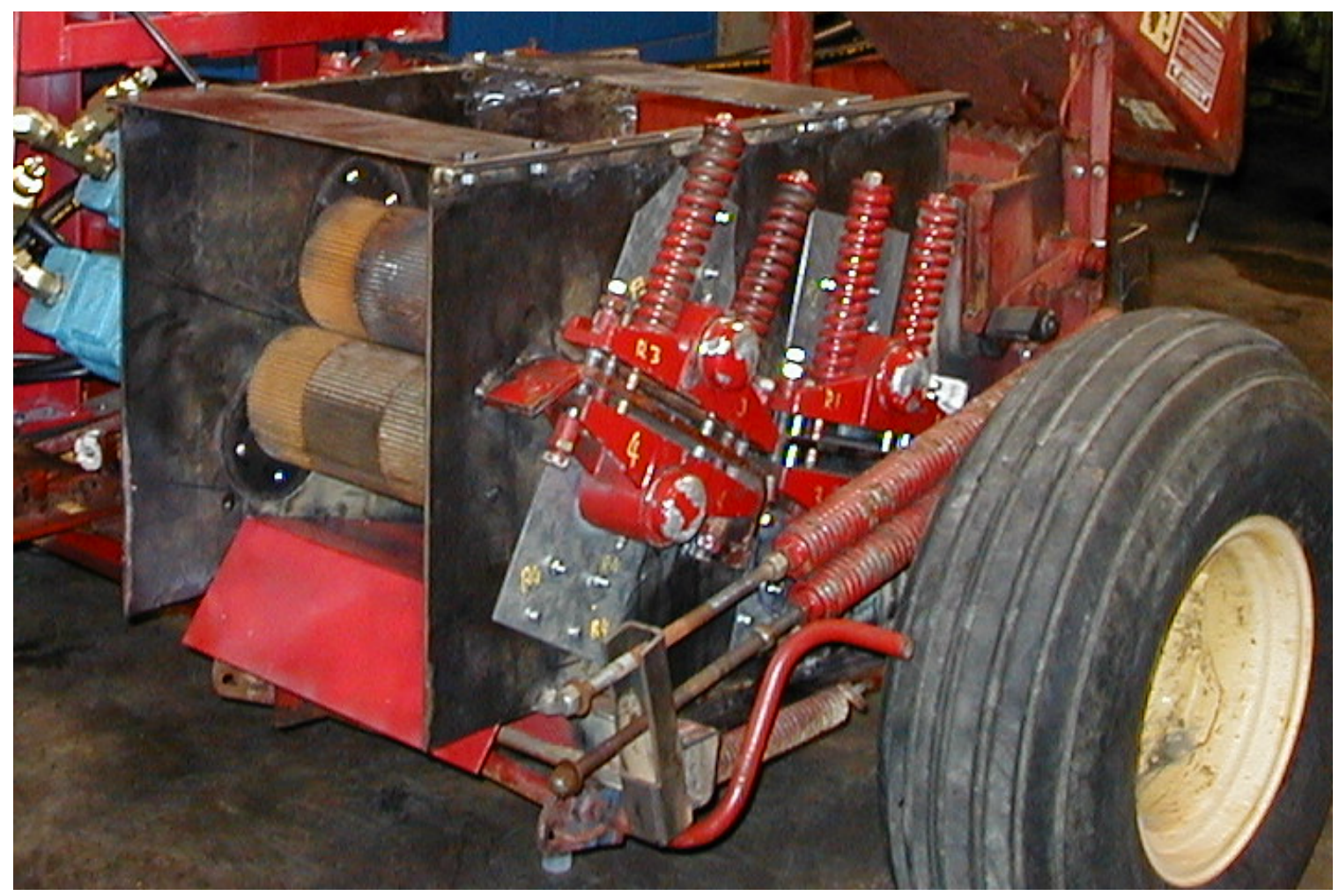

Figure 2. Assembled shredding chamber on the pull-type harvester.

Table 1. Target speed configurations of the shredding rolls used during testing.

\begin{tabular}{|c|c|c|c|c|c|c|}
\hline \multirow[b]{3}{*}{$\begin{array}{l}\text { Roll } \\
\text { Speed }\end{array}$} & \multirow{3}{*}{$\begin{array}{c}\text { Speed } \\
\text { Difference } \\
\text { within } \\
\text { Roll Pairs } \\
(\%)^{[\mathrm{a}]}\end{array}$} & \multirow{3}{*}{$\begin{array}{c}\text { Speed } \\
\text { Difference } \\
\text { between } \\
\text { Roll Pairs } \\
(\%)^{[\mathrm{a}]}\end{array}$} & \multicolumn{4}{|c|}{ Target Speeds (rpm) } \\
\hline & & & \multicolumn{2}{|c|}{ Front Pair } & \multicolumn{2}{|c|}{ Rear Pair } \\
\hline & & & $\begin{array}{c}\text { Roll } \\
1\end{array}$ & $\begin{array}{c}\text { Roll } \\
2\end{array}$ & $\begin{array}{c}\text { Roll } \\
3\end{array}$ & $\begin{array}{c}\text { Roll } \\
4\end{array}$ \\
\hline A & 15 & 30 & 1600 & 1390 & 2080 & 1810 \\
\hline B & 15 & 60 & 1300 & 1130 & 2080 & 1810 \\
\hline $\mathrm{C}$ & 30 & 30 & 1600 & 1230 & 2080 & 1600 \\
\hline $\mathrm{D}$ & 30 & 60 & 1300 & 1000 & 2080 & 1600 \\
\hline
\end{tabular}

[a] Speed difference $\%=\left(\right.$ speed difference ${ }_{\mathrm{rpm}} /$ slower $_{\text {speed }}$ rpm $\left._{\mathrm{rpm}}\right) \times 100$.

unit roll force, crop moisture content, machine throughput, and flail configuration. Table 1 lists the target roll speed configurations tested; speed differences within roll pairs were chosen to bracket speed differentials of current crop processors $(15 \%$ to $20 \%)$. Settings of minimum roll clearance for the rear pair was either 1 or $2 \mathrm{~mm}$, which is comparable to recommendations for crop processors used after chopping (Shinners et al., 2000). Minimum roll clearance settings for the front pair $(10$ or $15 \mathrm{~mm})$ were chosen to allow whole ears to feed into the harvester. Unit roll forces for the front and rear roll sets were set to three values (low, medium, and high; 15 , 30 , and $45 \mathrm{~N} / \mathrm{mm}$, respectively), which also cover the range of most current crop processors. Measures of performance included specific energy requirement, particle size distribution, and packed silage density.

Machine power requirements were estimated from the speeds of the hydraulic motors and the pressure drop across each motor. There was no adjustment for zero-flow power requirements. The power and energy were based on an assumed $85 \%$ mechanical efficiency of the hydraulic gear motors. A data logger (Campbell Scientific 21X) sampled at $0.25 \mathrm{~Hz}$ and recorded averaged data at $2 \mathrm{~Hz}$ from the speed sensors and pressure transducers. Machine throughput over the typical $100 \mathrm{~m}$ runs was estimated from travel time, travel distance, and crop yield. Crop yield was estimated with three replicate strips hand harvested in an area adjacent to the test strips. Specific energy was total machine power requirement divided by the throughput.

During fall 2000, two sets of experiments focused on the effect of machine configuration on energy consumption and particle size reduction; during a third experiment, samples were collected to make silage in laboratory-scale silos. The silage was examined for particle size distribution, packed density, and visually appraised quality. During 2001, the effects of crop moisture content, throughput, and roll speed configuration on machine energy consumption, particle size distributions, and packed silage density were investigated. For silage density and particle size evaluation, forage samples were collected with the flail cutting mechanism in place.

For each test condition, hydraulic motor speeds and pressures were recorded in three sessions (nominally $40 \mathrm{~s}$ each), and one bag of sample was collected. This was done in two steps. First, the three sessions of data were collected without stopping the machine. Second, the machine was stopped to have a plastic bag attached to the shredding chamber and then run for about $10 \mathrm{~s}$ to fill the bag. Particle size distribution was determined using the ASAE S424.1 particle separator (ASAE Standards, 2002b). Packed density was determined using laboratory-scale silos compacted using a hydraulically powered packing device (Hoover, 1998). Silage from the laboratory-scale silos was evaluated for $\mathrm{pH}$. 


\section{Experiments 1, 2, and 3: Preliminary Shredding Tests}

During experiment 1 (September 29, 2000), whole-plant moisture content was $67 \%$ w.b. Experiment 1 included all four speed configurations (A, B, C, and D in table 1) and two unit roll forces (low and medium); the minimum roll clearance was set at $10 \mathrm{~mm}$ for the front rolls and $2 \mathrm{~mm}$ for the rear rolls.

During experiment 2 (October 6, 2000), crop moisture content was $62 \%$ w.b. Two roll speed configurations, A and C (table 1), were selected based on previous results. Minimum roll clearance was set to $10 \mathrm{~mm}$ for the front rolls and $1 \mathrm{~mm}$ for the rear rolls, while unit roll force for both pair of rolls was low, medium, and high for a total of six treatments in a first subset of experiments. In the second subset, unit roll force was high for the rear rolls and low for the front rolls, while the minimum roll clearance was $10 \mathrm{~mm}$ (front) and $2 \mathrm{~mm}$ (rear) for a total of two treatments. In the third subset of experiments, speed configurations B and D (table 1) were tested with minimum roll clearances of $10 \mathrm{~mm}$ (front) and $1 \mathrm{~mm}$ (rear), while unit roll force was set to values that worked well during prior testing (low front and high rear).

For experiment 3 , the minimum roll clearance setting of $10 \mathrm{~mm}$ (front) and $1 \mathrm{~mm}$ (rear) was tested at all four speed configurations (A, B, C, and D in table 1). Experiment 3 was done on October 11, 2000, when whole-plant moisture content was $51 \%$ w.b.

\section{EXPeriments 4 AND 5: EfFect of Moisture Content AND ThroughPUT}

Moisture level, tractor ground speed, roll speed configuration, and front roll clearance were varied in experiment 4. Two roll speed configurations ( $\mathrm{A}$ and $\mathrm{C}$ in table 1 ) were examined. Minimum front roll clearances of $15 \mathrm{~mm}$ and $10 \mathrm{~mm}$ were examined at $65 \%$ and $60 \%$ w.b. moisture levels. Minimum front roll clearance was expanded to $15 \mathrm{~mm}$ when harvesting the $65 \%$ w.b. moisture crop in an attempt to improve material flow into the shredding rolls.

Factors varied in experiment 5 included roll clearance and moisture content. Four silos were packed for each experimental condition using the device and process developed by Hoover (1998). In the beginning of the experiment, both shredded-only and shredded and flail-cut samples were collected to fill laboratory-scale silos. Later, the shreddedonly samples without cutting were deemed too long in particle size for practical storage in bunker silos or bag silos; therefore, only shredded and flail-cut samples were used to fill laboratory-scale silos. For the $70 \%$ w.b. moisture level, the rear set of rolls had a $2 \mathrm{~mm}$ roll clearance when the flail cutter was used. Later experiments showed that the $2 \mathrm{~mm}$ rear roll clearance produced very coarse particles, so the $2 \mathrm{~mm}$ setting was eliminated for $65 \%$ and $60 \%$ w.b. moisture levels. With the $1 \mathrm{~mm}$ clearance for the rear rolls, sample particles looked smaller, with the lower part of the stalks sliced into thin sections.

Samples were also collected from a conventional forage harvester to make laboratory-scale silos for comparison. Theoretical length of cut for the conventional chopper was set at $9.5 \mathrm{~mm}$ for all experiments. Four silos were packed for each moisture level.

\section{Experiment with Flail Cutter: Effect of Flail} Configuration and Crop Moisture Content

With whole-plant moisture targets of $70 \%, 65 \%$, and $60 \%$ w.b., the rotor was tested at two different speeds: $1800 \mathrm{rpm}$ and $2100 \mathrm{rpm}$. For each rotor speed, the number of flail impacts per revolution was varied to include 2, 3, and 4. For each setting, power data (estimated from speed and pressure drop across the hydraulic motor) were collected from three runs of approximately $40 \mathrm{~s}$ each.

Samples were collected for each machine setting for particle size analysis. Material collected in a trailed wagon was sub-sampled twice. Because the shredded corn has a very large proportion of long particles on the top screen of the ASAE particle size separator (ASAE Standards, 2002b), this material was hand sorted into two piles: greater or less than $150 \mathrm{~mm}$. On each day of harvest, moisture content of the sampled material was determined by oven drying at $103^{\circ} \mathrm{C}$ for $24 \mathrm{~h}$ (ASAE Standards, 2002a).

\section{ReSUlTS AND DiscusSiON}

Nearly 50 trials were run with the shredding harvester with various settings of roll speed difference, minimum roll clearance, whole-plant moisture, and throughput. Details of results are included in Zhang (2002) and Sword (2002). Throughout the trials, it was evident that speed ratio treatments $\mathrm{A}$ and $\mathrm{C}$ (table 1) yielded better machine performance (less plugging). Kernels and cobs were completely broken, and the corn stalk and leaf (forage portion) were intensively shredded. Machine capacity appeared to be limited primarily due to poor feeding from the head and feed rolls and a poorly designed spout behind the flail cutter/blower; the rear processing rolls never plugged with the settings tested.

\section{SPECIFIC ENERGY FOR SHREDDING}

Specific energy for shredding ranged from 2.5 to $5.9 \mathrm{kWh} /$ Mg DM (0.88 to $1.88 \mathrm{kWh} / \mathrm{Mg}$ ) over all conditions tested and averaged $3.6 \mathrm{kWh} / \mathrm{Mg}$ DM $(1.29 \mathrm{kWh} / \mathrm{Mg})$. Roberge et al. (1999), with similar (relatively low) mass flow rates found that the specific energy for corn chopping, processing, and blowing was $6.6 \mathrm{kWh} / \mathrm{Mg} \mathrm{DM}$, with $1.2 \mathrm{kWh} / \mathrm{Mg} \mathrm{DM}$ for processing. Comparatively, the $3.6 \mathrm{kWh} / \mathrm{Mg} \mathrm{DM}$ average from this study does not include the flail cutting/blowing. Shinners et al. (2000) reported a total harvester specific energy of 2.2 to $2.7 \mathrm{kWh} / \mathrm{Mg}$; the average $1.29 \mathrm{kWh} / \mathrm{Mg}$ for shredding only from this study suggests that even with supplementary cutting or blowing, the shredding plus flail cutting/blowing process should be energetically competitive. This is consistent with the observation of Shinners et al. (1987a) that longitudinal shear (shredding) takes less energy less than transverse shear (cutting).

On average, the rear roll pair required $76 \%$ more power than the front pair. The ratio of peak (95th percentile) to average power requirement ranged from 1.5 to 2.5 among the various runs, with an average of 1.9. While average specific energy reflects energy requirement, the peak determines the size of the power unit required. The relatively large peak-to-average ratio was likely due to the unsteady feeding from the head and feed rolls into the first pair of processing rolls. 
Table 2. Correlation coefficients of experimental variables to specific energy for shredding through two sets of toothed rolls.

\begin{tabular}{lcccc}
\hline Variable & $\begin{array}{c}\text { Specific Energy } \\
\text { of Front Roll Pair } \\
(\mathrm{kWh} / \mathrm{Mg} \text { DM })\end{array}$ & $\begin{array}{c}\text { Specific Energy } \\
\text { of Rear Roll Pair } \\
(\mathrm{kWh} / \mathrm{Mg} \text { DM })\end{array}$ & $\begin{array}{c}\text { Total Specific Energy } \\
\text { on DM Basis } \\
(\mathrm{kWh} / \mathrm{Mg} \mathrm{DM})\end{array}$ & $\begin{array}{c}\text { Total Specific Energy } \\
\text { on Wet Basis } \\
(\mathrm{kWh} / \mathrm{Mg})\end{array}$ \\
\hline Moisture & 0.59 & 0.1 & 0.37 & -0.09 \\
Throughput & -0.58 & -0.45 & -0.57 & -0.39 \\
Speed difference within pairs & 0.06 & -0.17 & -0.06 & -0.08 \\
Speed difference between pairs & -27 & -0.17 & -0.26 & -0.28 \\
Front roll pressure & -0.08 & -0.29 & -0.27 & -0.29 \\
Rear roll pressure & 0.20 & 0.34 & 0.35 & 0.39 \\
Front roll minimum clearance & -0.22 & 0.23 & 0.05 & 0.28 \\
Rear roll minimum clearance & -0.10 & -0.38 & -0.33 & -0.39 \\
\hline
\end{tabular}

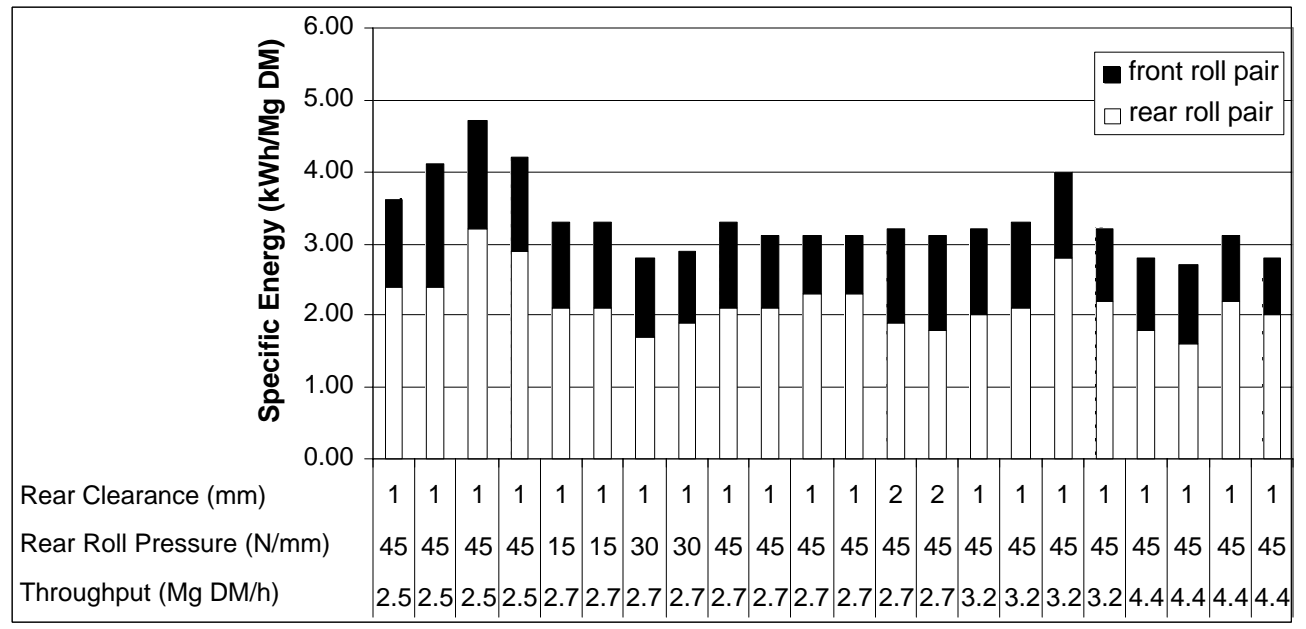

Figure 3. Specific energy requirement for shredding $60 \%$ to $62 \%$ w.b. moisture whole-plant corn with two pairs of rolls as affected by minimum rear roll clearance, rear roll pressure, and throughput.

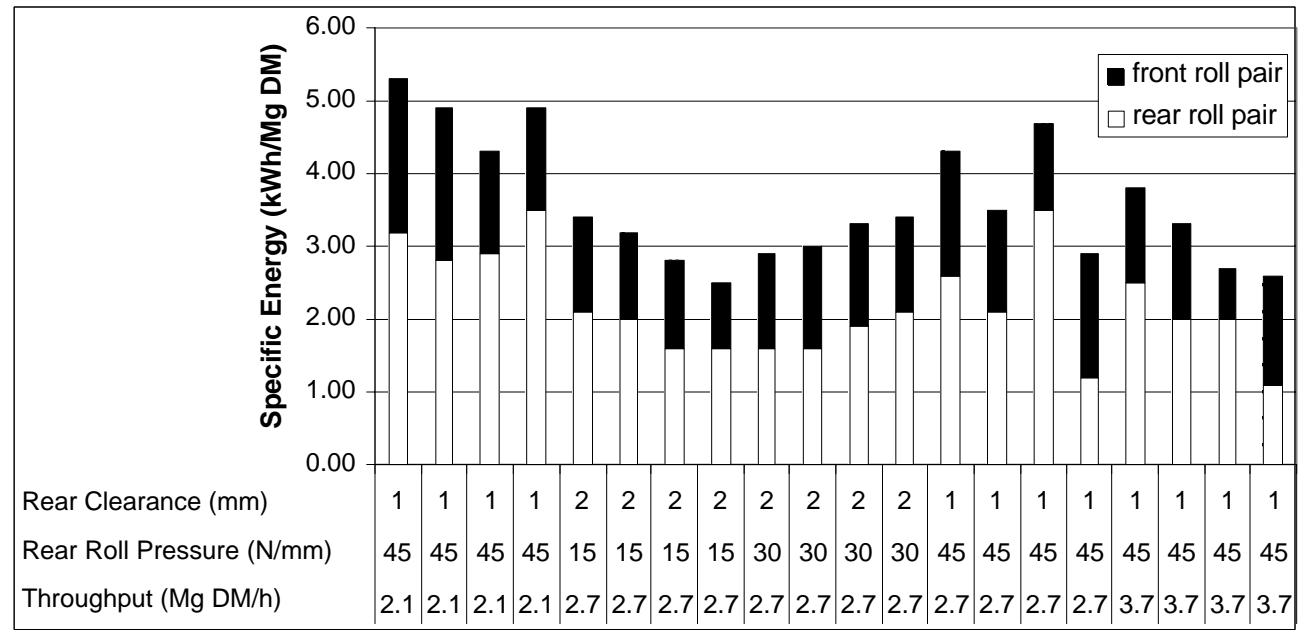

Figure 4. Specific energy requirement for shredding $65 \%$ w.b. moisture whole-plant corn with two pairs of rolls as affected by minimum rear roll clearance, rear roll pressure, and throughput.

Correlation coefficients of the variables to specific energy required for shredding are listed in table 2 . For the front roll pair, moisture and throughput were most highly correlated to specific energy required; for the rear pair, throughput, rear roll pressure, and rear roll minimum clearance were most highly correlated. Whether specific energy was expressed on a dry matter basis $(\mathrm{kWh} / \mathrm{Mg} \mathrm{DM})$ or a wet material flow basis $(\mathrm{kWh} / \mathrm{Mg})$, the variables with strongest correlations to total shredding specific energy were throughput, rear roll pressure, and rear roll minimum clearance. Average specific energy requirement is plotted for many machine configurations in figures 3,4 , and 5 with these variables noted.

In addition to the correlation analysis, a linear regression analysis of specific energy was used to identify which independent variables explained significant portions of the specific shredding energy. For the front roll pair alone, moisture $(p<0.01)$ and throughput $(p<0.01)$ significantly affected specific energy. For the rear roll pair, throughput $(p<0.01)$ and rear roll minimum clearance $(p<0.10)$ were significant factors. For total specific energy on a dry matter basis, throughput $(\mathrm{p}<0.01)$, rear roll pressure $(\mathrm{p}<0.05)$, and 


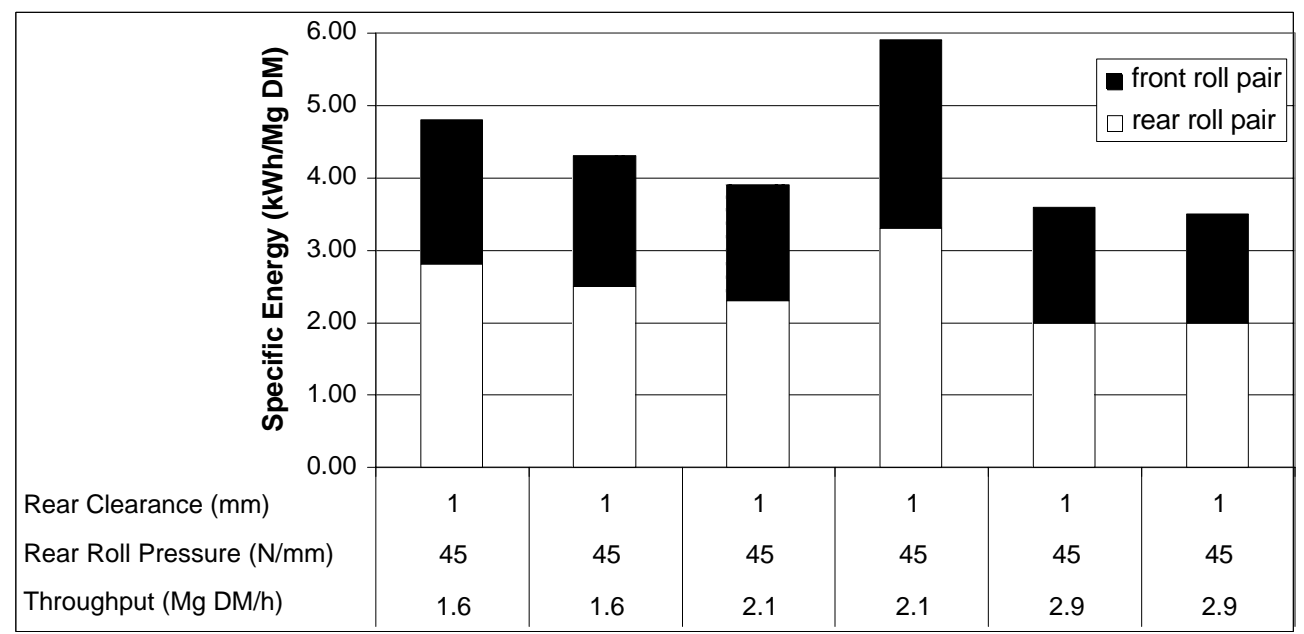

Figure 5. Specific energy requirement for shredding $70 \%$ w.b. moisture whole-plant corn with two pairs of rolls as affected by minimum rear roll clearance, rear roll pressure, and throughput.

rear roll minimum clearance $(\mathrm{p}<0.10)$ were significant factors. With specific energy on a wet basis, moisture $(\mathrm{p}<0.01)$, throughput $(\mathrm{p}<0.01)$, rear roll pressure $(\mathrm{p}<0.05)$, and rear roll minimum clearance $(\mathrm{p}<0.10)$ were significant factors. An increase in specific energy due to low throughput, higher rear roll pressure, and lower rear roll minimum clearance can be seen in figures 3,4 , and 5 .

\section{Specific Energy for Flail Cutting/Blowing}

Specific energy for the flail cutter/blower ranged from 2.0 to $4.7 \mathrm{kWh} / \mathrm{Mg} \mathrm{DM}$ (0.51 to $1.2 \mathrm{kWh} / \mathrm{Mg}$ ) (fig. 6). Both moisture and flail speed were highly correlated to specific energy, but the number of flails was not (table 3). Regression analysis indicated that moisture and flail speed significantly $(\mathrm{p}<0.01)$ helped explain flail cut/blow specific energy. The ratio of peak (95th percentile) to average power requirement for the flail cutter/blower ranged from 2.0 to 3.0, with an average of 2.5. This large value was largely due to the poor feeding of the feed rolls into the first pair of processing rolls.

\section{Particle Size}

Kernels and cobs from processed corn with the 1 or $2 \mathrm{~mm}$ rear roll clearance were completely broken, with no identifiable kernel pieces larger than approximately $1 / 4$ kernel. All kernel and cob portions were smaller than $6 \mathrm{~mm}$, falling through the fourth sieve of the ASAE S424.1 particle size separator (ASAE Standards, 2002b). The fodder appeared more shredded (likely more surface area) with the $1 \mathrm{~mm}$ minimum roll clearance than with the $2 \mathrm{~mm}$ setting. Without any cutting, the harvested material was very heterogeneous. Corn stalks were shredded and torn apart, and ears were completely processed; however, leaves remained almost intact, and overall particle sizes were very long $(>20 \mathrm{~cm})$. Some $\mathrm{sec}-$ tions of stalk remained unflattened. Analyses of particle sizes of shredded-only silage are included in Zhang (2002) but are not included here since the thinner and shorter material produced with the added flail cutter was deemed more suitable for commercial silage making.

Table 3. Correlation coefficients of experimental variables to specific energy for flail cutting/blowing after shredding.

\begin{tabular}{lcc}
\hline & \multicolumn{2}{c}{ Correlation to Specific Energy } \\
\cline { 2 - 3 } Variable & $\begin{array}{c}\text { DM Basis } \\
(\mathrm{kWh} / \mathrm{Mg} \mathrm{DM})\end{array}$ & $\begin{array}{c}\text { Wet Basis } \\
(\mathrm{kWh} / \mathrm{Mg})\end{array}$ \\
\hline Moisture & 0.75 & 0.89 \\
Number of flails & -0.02 & -0.02 \\
Flail tip speed & 0.58 & 0.36 \\
\hline
\end{tabular}

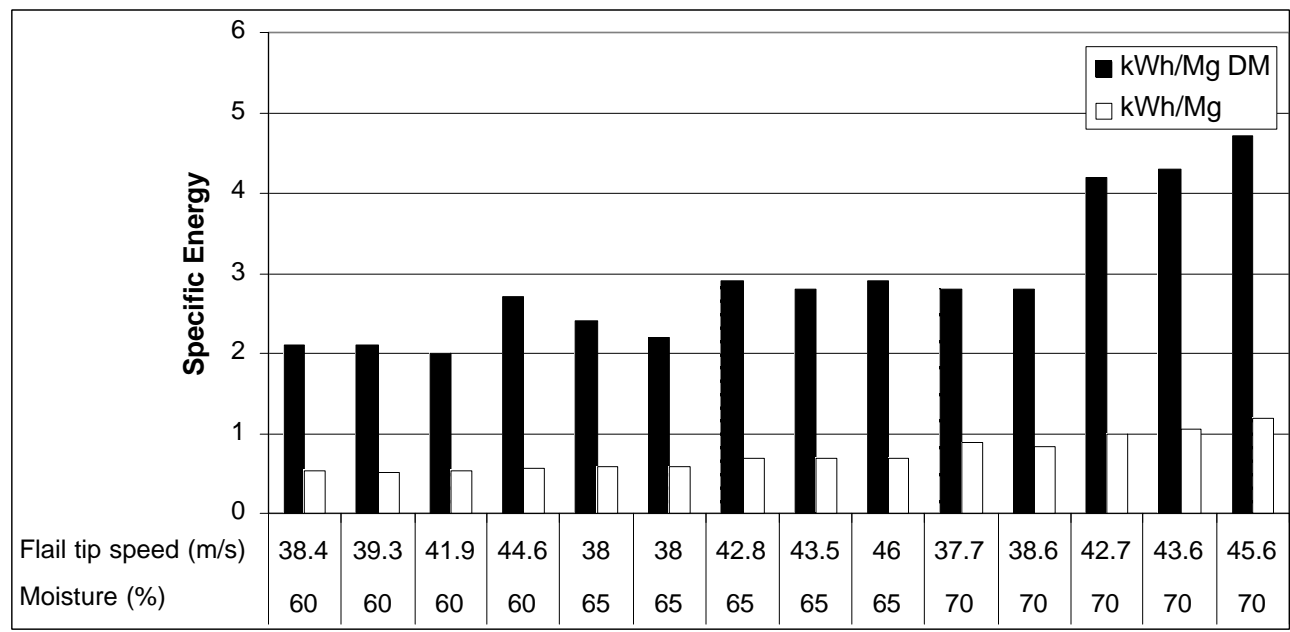

Figure 6. Specific energy requirement for flail cutting/blowing whole-plant corn after shredding as affected by flail tip speed and moisture content. 


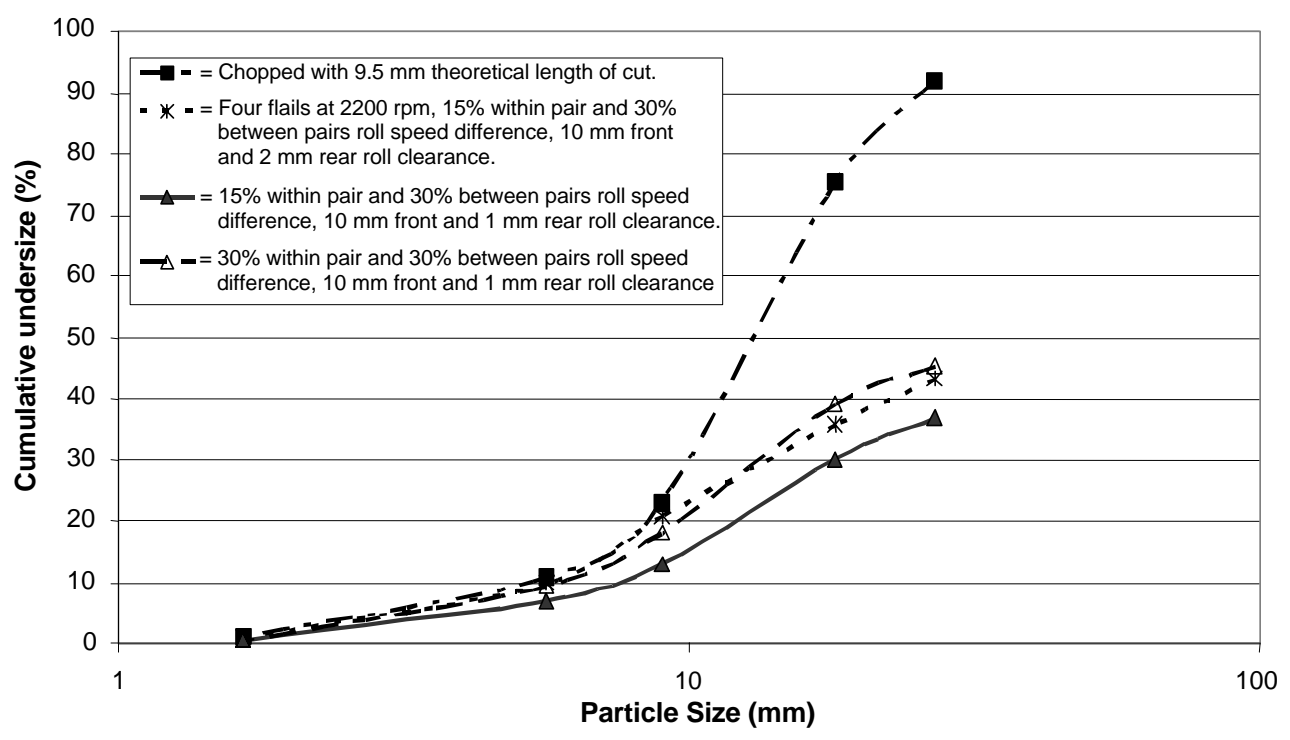

Figure 7. Particle size distribution of chopped or shredded whole-plant corn at $70 \%$ w.b. moisture.

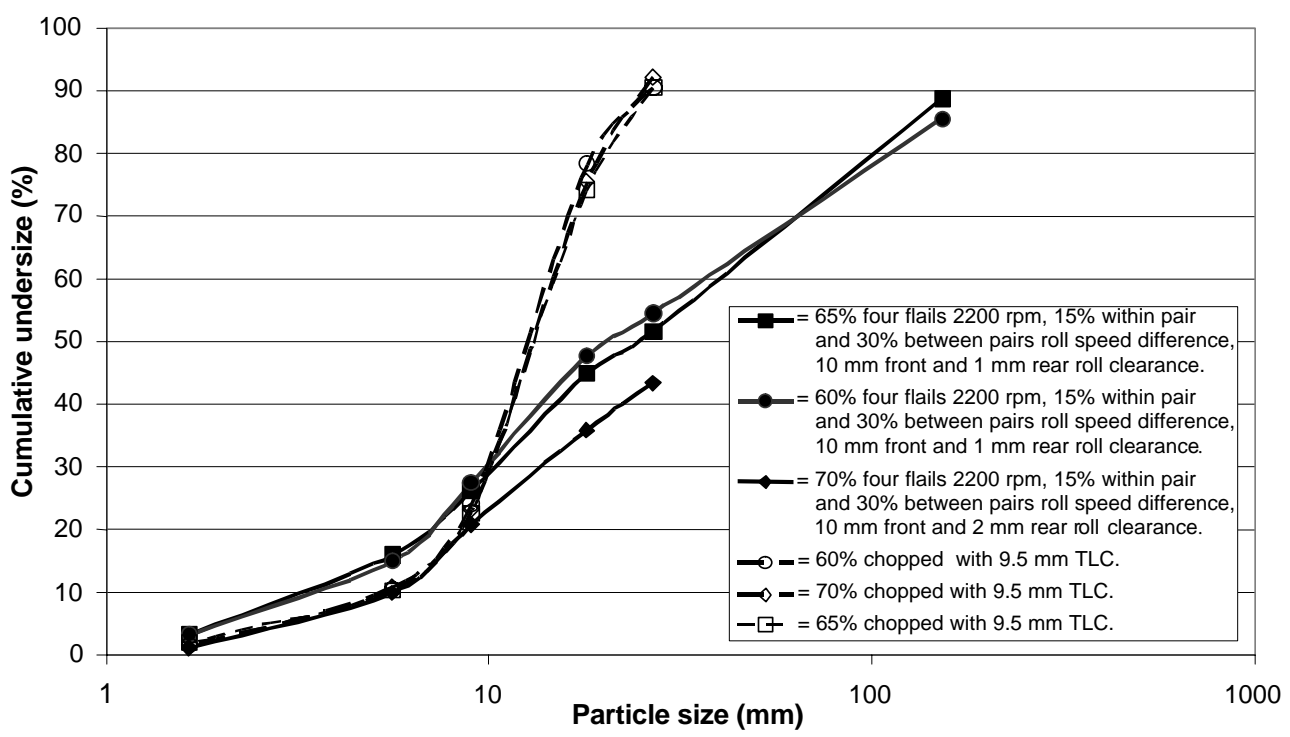

Figure 8. Particle size distributions of chopped samples and samples processed with a flail cutter for three moisture levels.

Figure 7 illustrates the particle size distribution of samples collected for laboratory-scale silos with a forage moisture content of $70 \%$ w.b. Between the two samples of shredded (without flail cutting) forage, roll speed configuration $\mathrm{C}$ produced more short particle mass than roll speed configuration A, but the two particle size distributions followed a very similar trend. The particle size distribution curve for flail-cut forage was similar to the curve for shredded forage with speed configuration C. Chopped forage and flail-cut forage had approximately the same amount of fine particles, with about $10 \%$ of sample mass smaller than $5.6 \mathrm{~mm}$. Approximately $20 \%$ of sample mass was smaller than $9 \mathrm{~mm}$ in both chopped and flail-cut forage. For particles larger than $9 \mathrm{~mm}$, flail-cut samples had more very large particles than chopped samples. About $45 \%$ of the sample mass was smaller than $26.9 \mathrm{~mm}$ in flail-cut forage versus about $90 \%$ in chopped forage.

Figure 8 shows that chopped forage had the largest portion of small particles, while the particle size distributions of flail-cut forage and shredded forage were similar. In reality, the flail cutter significantly reduced large particles coming from the shredding rolls, but the data failed to show this reduction because, due to the sieve sizes of the ASAE separator (ASAE Standards, 2002b), about the same percentage of large particles were left on the top feeder and the first screen for both flail-cut and shredded forages. Figure 8 shows the particle size distribution with hand separation of long particle mass for the corn harvested at $60 \%$ and $65 \%$ w.b. moisture. Particle size distribution of chopped samples was also included in the chart for comparison; the shredded silage has a much wider particle size distribution.

Chopped samples yielded very similar particle size distributions at all three moisture levels. Particle size distributions of flail-cut samples were similar between $60 \%$ and $65 \%$ w.b. moisture content, but the $70 \%$ w.b. moisture crop was most coarse. This difference is most likely due to the larger $(2 \mathrm{~mm}$ rather than $1 \mathrm{~mm}$ ) minimum clearance of the rear roll pair at this moisture. Compared to chopped corn, shredded corn had fewer particles smaller than $9 \mathrm{~mm}$ (fig. 7); 
flail-cut corn had more fine particles $(<9 \mathrm{~mm})$ and more large (>19 mm) particles (fig. 8). Results with 51\% w.b. moisture crop in year 2000 also showed that shredding produced fewer fine particles and more large particles compared to chopping (Zhang, 2002). Fine particles include grains, shredded cobs, and leaves. The use of a flail cutter increased the amount of fines while still leaving an abundance of long shredded particles.

\section{Silage Density}

Despite the long length, the silage ensiled well in laboratory-scale silos; only small spots of mold were noticed on the outer surface of the lab silos. Minor molding such as this is common even with conventionally harvested samples. Both the smell and color of silage was normal. The $\mathrm{pH}$ of silage ranged from 3.8 to 4.1 after fermentation, indicating adequate fermentation. This is consistent with shredded silage stored in a horizontal bag silo as part of a related study (Sword and Buckmaster, 2002); it, too, fermented very well and experienced excellent animal acceptance.

Silage densities from laboratory-scale silos are shown in table 4. An analysis of variance of the density of both chopped and flail-cut samples showed that the interaction between moisture content and harvesting method was not significant $(p<0.05)$. For the main effects, both moisture content and harvesting method affected silage density. Tukey's Studentized range test was used to identify significant differences in levels (Devore, 1999, pp. 402-455). There was no significant difference in silage density between $60 \%$ and $70 \%$ w.b. moisture; samples obtained at $65 \%$ w.b. moisture had significantly higher average density than those obtained at $60 \%$ and $70 \%$ w.b. moisture. Comparison between harvesting methods showed a significant difference between shredding plus flail cutting and chopping. Chopped silage had significantly $(\mathrm{p}<0.05)$ higher densities (average $199 \mathrm{~kg} \mathrm{DM} / \mathrm{m}^{3}$ ) than flail-cut silage (average $168 \mathrm{~kg}$ $\mathrm{DM} / \mathrm{m}^{3}$ ), but both were adequate for good ensiling.

\section{Conclusions}

The following conclusions can be drawn from this study:

- The shredding forage harvester worked successfully in the field under various crop and machine conditions, but feeding into the front processing rolls was unsteady. The machine functioned best (least plugging) with speed differences of $30 \%$ between the roll pairs.

- Specific energy required for shredding averaged 2.5 to $5.9 \mathrm{kWh} / \mathrm{Mg}$ DM for the conditions tested. Specific shredding energy was not significantly affected by front roll pressure, speed difference, or minimum front roll clearance. Specific shredding energy increased as throughput decreased, rear roll pressure increased, and rear roll minimum clearance decreased.

- The average specific energy requirement for flail cutting/ blowing ranged from 2.0 to $4.7 \mathrm{kWh} / \mathrm{Mg}$. Average specific energy of the flail cutter/blower tended to increase with increasing moisture content and flail tip speed.

- Shredding alone (without flail cutting) produced fewer fine particles and more large particles compared to chopping. Compared to chopped samples, flail-cut samples had more fine particles and more large particles. The use
Table 4. Silage densities of laboratory-scale silos chopped with $9.5 \mathrm{~mm}$ theoretical length of cut or shredded and flail cut with four flails at $2200 \mathrm{rpm}$.

\begin{tabular}{cccc}
\hline $\begin{array}{c}\text { Moisture } \\
\text { Content } \\
(\% \text { w.b. })\end{array}$ & $\begin{array}{c}\text { Harvesting } \\
\text { Method }\end{array}$ & $\begin{array}{c}\text { Average Dry } \\
\text { Matter Density } \\
\left(\mathrm{kg} \mathrm{DM} / \mathrm{m}^{3}\right)^{[\mathrm{a}]}\end{array}$ & $\begin{array}{c}\text { Standard } \\
\text { Deviation } \\
\left(\mathrm{kg} \mathrm{DM} / \mathrm{m}^{3}\right)\end{array}$ \\
\hline 70 & Chop & $197 \mathrm{aA}$ & 4.4 \\
& Shred and flail & $163 \mathrm{bA}$ & 6.2 \\
& Shredded & 142 & 3.5 \\
\hline 65 & Chop & $206 \mathrm{aB}$ & 6.0 \\
& Shred and flail & $176 \mathrm{bB}$ & 3.6 \\
\hline 60 & Chop & $195 \mathrm{aA}$ & 7.6 \\
& Shred and flail & $163 \mathrm{bA}$ & 8.7 \\
\hline
\end{tabular}

[a] Similar lowercase letters indicate values between harvesting methods (chop vs. flail-cut) were not significantly different by analysis of variance $(\mathrm{p}<0.05)$. Similar uppercase letters indicate values among moisture levels were not significantly different by Tukey's Studentized range test $(\mathrm{p}<0.05)$.

of a flail cutter increased the amount of fines while still leaving an abundance of long shredded particles.

- Shredded and flail-cut silage at $65 \%$ w.b. moisture had higher DM densities than shredded and flail-cut silage at $70 \%$ and $60 \%$ w.b. moistures. The density of shredded and flail-cut silage was approximately $80 \%$ of the density of chopped silage.

\section{REFERENCES}

Armentano, L., and M. Pereira. 1997. Measuring the effectiveness of fiber by animal response trials. J. Dairy Science 80(7): $1416-1425$.

ASAE Standards. 2002a. S358.2: Moisture measurement - forages. St. Joseph, Mich.: ASAE.

ASAE Standard. 2002b. S424.1: Method of determining and expressing particle size of chopped forage materials by screening. St. Joseph, Mich.: ASAE.

Bal, M. A., R. D. Shaver, A. G. Jirovec, K. J. Shinners, and J. G. Coors. 2000. Crop processing and chop length of corn silage: Effects on intake, digestion, and milk production by dairy cows. J. Dairy Science 83(6): 1264-1273.

Cauffman, G. R. 2002. Design and fabrication of a hydraulic variable-speed forage shredding harvester and achieving field performance of the prototype machine. M. Agr. paper in agricultural mechanization. University Park, Pa.: Pennylvania State University.

Charmley, E., P. Savoie, and R. E. McQueen. 1997. Influence of maceration at cutting on lactic acid bacteria populations, silage fermentation, and voluntary intake and digestibility of precision-chopped lucerne silage. Grass and Forage Science 52(1): 110-121.

Chattopadhyay, P. S., and K. P. Pandey. 2001. Influence of knife configuration and tip speed on conveyance in flail forage harvesting. J. Agric. Eng. Research 78(3): 245-252.

Devore, J. L. 1999. Probability and Statistics for Engineering and the Sciences. 5th ed. Pacific Grove, Ca.: Duxbury.

Hintz, R. W., R. G. Koegel, T. J. Kraus, and D. R. Mertens. 1999. Mechanical maceration of alfalfa. J. Animal Science 77(1): 187-193.

Honig, H., and K. Rohr. 1982. The influence of chopping on losses by undigested kernels and kernel fragments of maize, when feeding ruminants. In Proc. Seminar on "Maize as basic feed for beef production," 32-41. H. J. Oslage and R. Daccord, eds. Braunschweig, Germany: FAL.

Hoover, L. L. 1998. Effects of pre-ensiled processing on nutritive quality, digestibility, particle size distribution, and compaction of 
corn silage. MS thesis. University Park, Pa.: Pennsylvania State University.

Hoover, L. L., D. R. Buckmaster, A. J. Heinrichs, and G. W. Roth. 1998. Particle size and compaction characteristics of mechanically processed corn silage at varying lengths of cut. ASAE Paper No. AETC-98103. St. Joseph, Mich.: ASAE.

Johnson, L. M. J. H. Harrison, C. Hunt, K. J. Shinners, C. G. Doggett, and D. Sapienza. 1999. Nutritive value of corn silage as affected by maturity and mechanical processing: A contemporary review. J. Dairy Science 82(12): 2813-2825.

Johnson, L. M., J. H. Harrison, D. Davidson, M. Swift, W. C. Mahanna, and K. J. Shinners. 2002. Corn silage management III: Effects of hybrid, maturity, and processing on nitrogen metabolism and ruminal fermentation. J. Dairy Science 85(11): 2928-2947.

Koegel R. G., R. J. Straub, K. J. Shinners, G. A. Broderick, and D. R. Mertens. 1992. An overview of physical treatments of lucerne performed at Madison, Wisconsin, for improving properties. $J$. Agric. Eng. Research 52(1): 183-191.

Nocek, J. E. 1997. Bovine acidosis: Implications on lameness. $J$. Dairy Science 80(5): 1005-1028.

Owens, F. N., D. S. Secrist, W. J. Hill, and D. R. Gill. 1998. Acidosis in cattle: A review. J. Animal Science 76(1): 275-286.

Petit, H. V., P. Savoie, D., Tremblay, G. T. Dossantos, and G. Butler. 1994. Intake, digestibility, and ruminal degradability of shredded hay. J. Dairy Science 77(12): 3043-3050.

Roberge, M., P. Savoie, and E. R. Norris. 1998. Evaluation of a crop processor in a pull-type forage harvester. Trans. ASAE. 41(4): 967-972.

Roberge, M., P. Savoie, and E. R. Norris. 1999. Forage crop processing: Effect of roll clearance and speed ratio. ASAE Paper No. AETC-99104. St. Joseph, Mich.: ASAE.
Rotz, C. A., L. M. Johnson, and J. H. Harrison. 1999. Economics of corn silage processing on North American dairy farms. Applied Eng. in Agric. 15(5): 411-421.

Savoie, P. 1997. Kernel processing: History and engineering. In Silage: Field to Feedbunk, 85-94. Publ. No. 99. Ithaca, N.Y.: Northeast Regional Agric. Eng. Service.

Shinners, K. J., R. G. Koegel, G. P. Barrington, and R. J. Straub. 1987a. Evaluating longitudinal shear as a forage maceration technique. Trans. ASAE 30(1): 18-22.

Shinners, K. J., R. G. Koegel, and R. J. Straub. 1987 b. Consolidation and compaction characteristics of macerated alfalfa used for silage production. ASAE Paper No. 871074. St. Joseph, Mich.: ASAE.

Shinners, K. J., R. G., Koegel, and P. J. Pritzl. 1991. An upward cutting cut-and-throw forage harvester to reduce machine energy requirements. Trans. ASAE 34(6): 2287-2290.

Shinners, K. J., A. G. Jirovec, R. D. Shaver, and M. Bal. 2000. Processing whole-plant corn silage with crop processing rolls on a pull-type forage harvester. Applied Eng. in Agric. 16(4): $323-331$

Sword, M. L. 2002. Improved silage - Utilizing shredding and flail cutting. MS thesis in agricultural and biological engineering. University Park, Pa.: Pennsylvania State University.

Sword, M. L., and D. R. Buckmaster. 2002. Shredding corn silage for improved effective fiber and less sorting. In Proc. American Forage and Grassland Conf., 95-99. Georgetown, Texas: American Forage and Grassland Council.

Zhang, M. 2002. Design and evaluation of a corn silage-making system with shredding. PhD diss. in agricultural and biological engineering. University Park, Pa.: Pennsylvania State University. Available at:

http://etda.libraries.psu.edu/theses/available/etd0413102-0930 01. 
